\title{
STUDI ANALISIS ION LOGAM Cu(II) DENGAN ASAM TANAT MENGGUNAKAN SPEKTROFOTOMETER ULTRAUNGU-TAMPAK
}

\author{
Rizka Ari Wandari ${ }^{1}$, R. Supriyanto ${ }^{2}$, dan Rinawati \\ ${ }^{1}$ Mahasiswa Jurusan Kimia FMIPA Universitas Lampung \\ ${ }^{2}$ Dosen Jurusan Kimia FMIPA Universitas Lampung \\ rizkaariwandari7@gmail.com
}

\begin{tabular}{|l|}
\hline Artikel Info \\
\hline Diterima tanggal \\
12.06 .2018 \\
Disetujui \\
publikasi tanggal \\
30.10 .2018 \\
\\
Kata kunci : \\
asam tanat, \\
gambir, Ion \\
Logam Cu(II), \\
spektrofotometer \\
ultraungu- \\
tampak \\
\hline
\end{tabular}

\section{ABSTRACT}

A study of ionic analysis of $\mathrm{Cu}$ (II) ion with tannic acid has been performed. This study aims to determine the maximum wavelength between $\mathrm{Cu}$ (II) ions with tannic acid and to obtain optimum conditions for $\mathrm{pH}$, concentration, volume, and stability time for complex compound $\mathrm{Cu}$ (II) ion - tannic acid. Analysis of $\mathrm{Cu}$ (II) ions with tannic acid was performed using an ultraviolet-visible spectrophotometer. The results of this study obtained the maximum wavelength of a complex compound $\mathrm{Cu}$ (II) ion - tannic acid was $473.5 \mathrm{~nm}$ with optimum conditions at $\mathrm{pH} 11$, stoichiometric ratio of variation in the concentration of $\mathrm{Cu}$ (II) ion - tannic acid was 1: 4, stoichiometric variation volume of $\mathrm{Cu}$ (II) ions tannic acid was $1: 1$, and stability time at $30^{\text {th }}$ minute. After the optimum variation was obtained then the method validation on $\mathrm{Cu}$ (II) ion obtained r-value of 0.9997 , in the precision test obtained value SD was 0.0124 and \% RSD was 1.4277. the value of LoD and LoQ were 0.2953 and 0.9844 , and the value of recovery (\% recovery) was $94.54 \%$.

\section{PENDAHULUAN}

Logam $\mathrm{Cu}$ digolongkan ke dalam logam berat esensial dalam konsentrasi yang sangat kecil, akan tetapi bila pada konsentrasi tinggi logam $\mathrm{Cu}$ akan menjadi racun bagi organisme hidup (Palar, 1994). Kadar maksimum yang diperbolehkan adalah 0,05-1,5 ppm. Logam $\mathrm{Cu}$ mempunyai bilangan oksidasi +1 dan +2 , akan tetapi jumlahnya yang melimpah adalah logam $\mathrm{Cu}$ dengan bilangan oksidasi +2 atau 
$\mathrm{Cu}(\mathrm{II})$, karena $\mathrm{Cu}(\mathrm{I})$ di air mengalami disproporsionasi membentuk senyawa yang tidak larut, sehingga $\mathrm{Cu}$ yang stabil adalah $\mathrm{Cu}(\mathrm{II})$ (Lee, 1994).

Analisis ion logam $\mathrm{Cu}$ (II) dilakukan dengan cara pembentukan kompleks ion logam $\mathrm{Cu}(\mathrm{II})$ dengan ligan asam tanat menggunakan spektrofotometer ultraungu-tampak. Asam tanat bila ditinjau dari struktur nya merupakan senyawa yang memiliki pasangan elektron bebas, baik pada gugus keton (pada keadaan polimer) dan gugus hidroksil (ketika ditambahkan basa atau asam pada saat pengaturan $\mathrm{pH}$ ). Pasangan elektron bebas ini dapat didonorkan kepada ion logam $\mathrm{Cu}$ yang memiliki orbital kosong, sehingga asam tanat merupakan suatu ligan yang dapat mendonorkan pasangan elektron bebas kepada ion logam $\mathrm{Cu}$ (Denny, 2007).

Beberapa optimasi yang akan dilakukan pada penelitian ini meliputi optimasi panjang gelombang ion logam $\mathrm{Cu}(\mathrm{II})$, optimasi panjang gelombang asam tanat, optimasi variasi $\mathrm{pH}$ dan panjang gelombang maksimum terhadap ion logam $\mathrm{Cu}(\mathrm{II})$ dan asam tanat, optimasi perbandingan konsentrasi antara asam tanat dengan ion logam $\mathrm{Cu}(\mathrm{II})$, optimasi volume asam tanat dan ion logam $\mathrm{Cu}(\mathrm{II})$, optimasi waktu kestabilan senyawa $\mathrm{Cu}$ (II) dan asam tanat, serta melakukan validasi metode yang meliputi penentuan liniearitas kurva kalibrasi, penentuan presisi, penentuan akurasi, penentuan LoD dan LoQ.

\section{METODE}

\section{Alat dan Bahan}

Alat-alat yang digunakan dalam penelitian ini adalah neraca analitik, spidol permanen, oven, gegep, loyang, botol plastik polietilen, spektromotometer ultraungu-tampak, $\mathrm{pH}$ meter, batang pengaduk, hotplate, spatula, mikro pipet dan alat gelas yang umum digunakan di laboratorium. Bahan yang digunakan adalah alumunium foil, asam tanat, akuades, akuabides, $\mathrm{CuSO}_{4} .5 \mathrm{H}_{2} \mathrm{O}$, dan $\mathrm{NaOH}$.

\section{Prosedur}

\section{Pembuatan Larutan Standar Asam Tanat dan Cu(II) 100 mM}

Ditimbang 17,012 gram asam tanat dan 2,4954 gram $\mathrm{CuSO}_{4} .5 \mathrm{H}_{2} \mathrm{O}$ menggunakan neraca analitik, kemudian dilarutkan menggunakan akuabides di dalam labu takar $100 \mathrm{ml}$ hingga tanda batas dan dihomogenkan.

\section{Pembuatan Larutan Penyangga}

Ditimbang 0,4 gram $\mathrm{NaOH}$ menggunakan neraca analitik kemudian dilarutkan menggunakan akuades dalam labu takar $100 \mathrm{ml}$ hingga tanda batas dan dihomogenkan. Kemudian dibuat larutan $\mathrm{pH}$ 
dengan menambahkan $\mathrm{NaOH} \mathrm{0,1} \mathrm{M} \mathrm{tetes} \mathrm{demi} \mathrm{tetes} \mathrm{dalam} 250 \mathrm{ml}$ akuades sampai terbentuk pH 8, 9, 10, 11 dan 12.

\section{Optimasi Panjang Gelombang Maksimum pada Ion Logam Cu(II) dan Asam Tanat}

Penentuan panjang gelombang optimum pada masing-masing larutan induk, yaitu $\mathrm{Cu}(\mathrm{II})$ dan asam tanat dengan konsentrasi masing-masing $1 \mathrm{mM}$ dan 0,01 $\mathrm{mM}$. Optimasi ini dilakukan dengan menggunakan spektrofotometer ultraungu-tampak.

\section{Penentuan Variasi pH dan Panjang Gelombang Maksimum Antara Ion Logam Cu(II) dengan Asam Tanat}

Penentuan variasi $\mathrm{pH}$ dilakukan dengan cara mereaksikan $\mathrm{Cu}$ (II) $1 \mathrm{mM}$ dengan asam tanat $1 \mathrm{mM}$ yang masing-masing telah diatur $\mathrm{pH} 8 ; 9 ; 10 ; 11$ dan 12 . Setelah itu dilakukan optimasi pada panjang gelombang optimum menggunakan spektrofotometer ultraungu-tampak.

\section{Penentuan Stoikiometri Antara Ion Logam Cu(II) dengan Asam Tanat: Penentuan Stoikiometri dengan Variasi Konsentrasi Asam Tanat (mM)}

Penentuan ini dilakukan dengan cara mengukur kompleks ion logam $\mathrm{Cu}$ (II) dengan asam tanat pada $\mathrm{pH}$ optimum dan panjang gelombang optimum dengan perbandingan konsentrasi ion logam $\mathrm{Cu}$ : asam tanat yaitu : 1:1, 1:2, 1:3, 1:4, dan 1:5 menggunakan spektrofotometer ultraungu-tampak.

\section{Penentuan Stoikiometri dengan Variasi Konsentrasi Ion Logam Tembaga (mM)}

Penentuan ini dilakukan dengan cara mengukur kompleks ion logam $\mathrm{Cu}(\mathrm{II})$ dengan asam tanat pada $\mathrm{pH}$ optimum dan panjang gelombang optimum dengan perbandingan konsentrasi ion logam $\mathrm{Cu}$ : asam tanat yaitu : 1:1, 2:1, 3:1, 4:1,dan 5:1 menggunakan spektrofotometer ultraungu-tampak.

\section{Penentuan Stokiometri dengan Variasi Volume Ion $\mathrm{Cu}(\mathrm{mL})$}

Penentuan dilakukan dengan cara mengukur kompleks Ion Logam $\mathrm{Cu}(\mathrm{II})$ dengan asam tanat pada pH optimum, konsentrasi optimum dan panjang gelombang optimum lalu memvariasikan volume ion logam $\mathrm{Cu}$ dengan perbandingan 1:1, 2:1, 3:1, 4:1, dan 5:1. menggunakan spektrofotometer ultraungutampak.

\section{Penentuan Stokiometri dengan Variasi Volume Asam Tanat (mL)}

Penentuan dilakukan dengan cara mengukur kompleks ion logam $\mathrm{Cu}(\mathrm{II})$ dengan asam tanat pada pH optimum, konsentrasi optimum dan panjang gelombang optimum lalu memvariasikan volume asam tanat dengan perbandingan 1:1, 1:2, 1:3, 1:4, dan 1:5. menggunakan spektrofotometer ultraungu-tampak. 


\section{Penentuan Waktu Kestabilan Kompleks Antara Asam Tanat dengan Cu(II)}

Penentuan waktu kestabilan kompleks dilakukan dengan perbandingan konsentrasi terbaik dan volume terbaik yang diperoleh, diukur absorbansinya dengan menggunakan Spektrofotometer UltraunguTampak pada panjang gelombang optimum dan $\mathrm{pH}$ optimum dari 0 menit sampai 60 menit dengan skala kenaikan 10 menit.

\section{Validasi Metode: Penentuan Liniearitas Kurva Kalibrasi Larutan Antara Ion Logam Cu(II)}

Dibuat larutan ion logam $\mathrm{Cu}$ (II) dan asam tanat dengan konsentrasi ion logam $\mathrm{Cu}(\mathrm{II})$ yang divariasikan yaitu $1 \mathrm{mM}, 3 \mathrm{mM}, 5 \mathrm{mM}, 7 \mathrm{mM}$ dan $9 \mathrm{mM}$. Kemudian ditambahkan asam tanat dengan konsentrasi optimum yaitu $6 \mathrm{mM}$. Diukur serapan atom maksimum dengan menggunakan spektrofotometer ultraungu-tampak. Nilai absorbansi yang diperoleh dibuat persamaan linear hubungan antara konsentrasi dengan absorbansi. Nilai r yang diperoleh menggambarkan linearitas.

\section{Penentuan Limit Deteksi (LoD) dan Limit Kuantifikasi (LoQ)}

Penentuan LoD dan LoQ untuk ion logam $\mathrm{Cu}$ (II) diperoleh dari pengukuran blanko kemudian hasil pengukuran dihitung berdasarkam persamaan kurva kalibrasi yang diperoleh.

\section{Penentuan Presisi}

Penentuan presisi dilakukan dengan mengukur konsentrasi sampel dengan 5 kali pengulangan. Nilai absorbansi yang telah diperoleh ditentukan nilai konsentrasi, simpangan baku (SD) serta nilai relatif standar deviasi (RSD). Metode dengan presisi yang baik ditunjukan dengan perolehan relatif standar deviasi $(\mathrm{RSD})<5 \%$.

\section{Penentuan Akurasi}

Penentuan akurasi dilakukan dengan menambahkan sejumlah analit murni ke dalam campuran. Kemudian campuran dianalisis dan hasilnya dibandingkan terhadap kadar analit yang ditambahkan (kadar sebenarnya). Jumlah analit yang ditambahkan ke dalam sampel atau selisih antara rata-rata dan nilai sebenarnya yang dapat didapat menunjukkan ketepatan. Ketepatan dihitung sebagai persen recovery (perolehan kembali).

\section{HASIL DAN PEMBAHASAN}

\section{Penentuan Panjang Gelombang Optimum Asam Tanat}

Larutan standar asam tanat 0,01 mM yang diencerkan dari larutan stok asam tanat 100 $\mathrm{mM}$ diukur dengan spektrofotometer ultraungu-tampak untuk menentukan panjang gelombang optimum dan absorbansi, dengan rentang panjang gelombang dimulai dari 200-350 nm. 
Panjang gelombang optimum yang diperoleh untuk standar asam tanat didapat pada 275,4 nm dengan absorbansi sebesar 0,779 seperti yang tertera pada Gambar 1 .

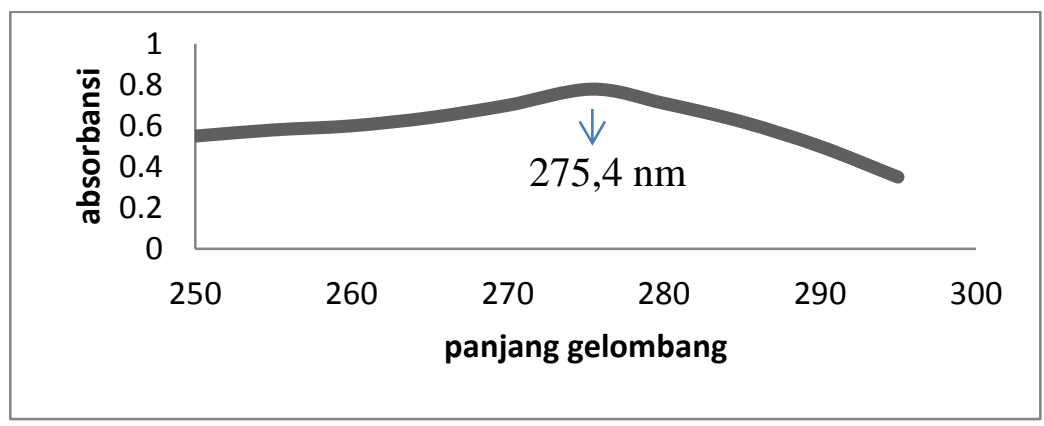

Gambar 1. Panjang gelombang optimum standar asam tanat

\section{Penentuan Panjang Gelombang Optimum Ion Logam Cu(II)}

Larutan $\mathrm{Cu}(\mathrm{II}) 1 \mathrm{mM}$ yang diencerkan dari larutan stok $\mathrm{Cu}$ (II) $100 \mathrm{mM}$ diukur dengan spektrofotometer ultraungu-tampak untuk menentukan panjang gelombang optimum dan absorbansi dengan rentang panjang gelombang dimulai dari 200-350 $\mathrm{nm}$. Panjang gelombang optimum yang diperoleh untuk standar larutan $\mathrm{Cu}$ (II) didapat pada 235,8 $\mathrm{nm}$ dengan absorbansi 0,702 yang tertera pada Gambar 2.

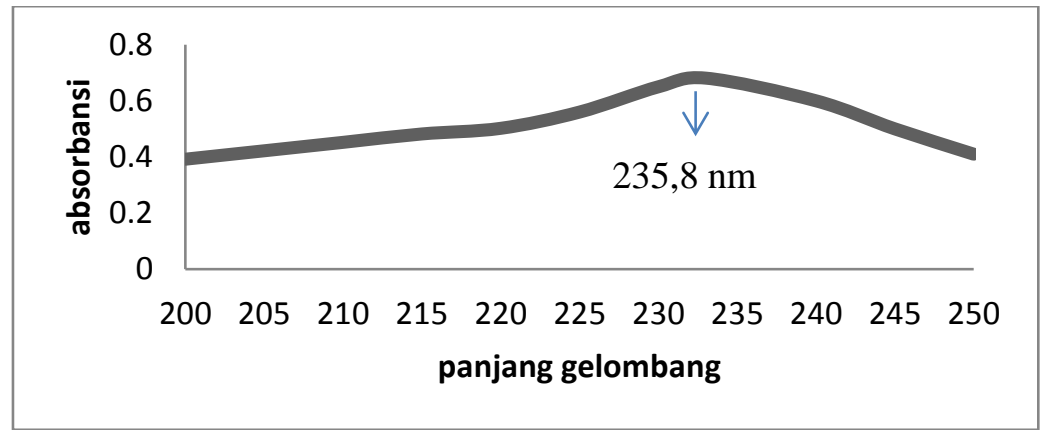

Gambar 2. Panjang gelombang optimum standar $\mathrm{Cu}(\mathrm{II})$

\section{Penentuan Variasi pH dan Panjang Gelombang Maksimum Antara Ion Logam Cu(II) dengan Asam Tanat}

Penentuan variasi $\mathrm{pH}$ dilakukan dengan cara mereaksikan $\mathrm{Cu}(\mathrm{II}) 1 \mathrm{mM}$ dan Asam Tanat 1 $\mathrm{mM}$ yang masing-masing telah diatur $\mathrm{pH} 8,9,10,11$ dan 12 dengan cara menambahkan larutan 
$\mathrm{NaOH}$. Optimasi panjang gelombang optimum menggunakan spektrofotometer ultraungutampak dilakukan pada rentang panjang gelombang $400-600 \mathrm{~nm}$.

Data yang dihasilkan untuk pengukuran $\mathrm{pH}$ dan panjang gelombang optimum antara ion logam $\mathrm{Cu}$ (II) dengan asam tanat dapat dilihat pada Tabel 1. Kurva panjang gelombang dapat dilihat pada Gambar 4.

Tabel 1. Penentuan variasi $\mathrm{pH}$ dan panjang gelombang Optimum antara ion logam $\mathrm{Cu}(\mathrm{II})$ dengan asam tanat

\begin{tabular}{rcc}
\hline $\mathrm{pH}$ & Panjang Gelombang & Absorbansi \\
\hline 8 & 460,0 & 0,709 \\
9 & 464,0 & 0,832 \\
10 & 468,0 & 0,889 \\
11 & 473,5 & 0,939 \\
12 & 470,0 & 0,909 \\
\hline
\end{tabular}

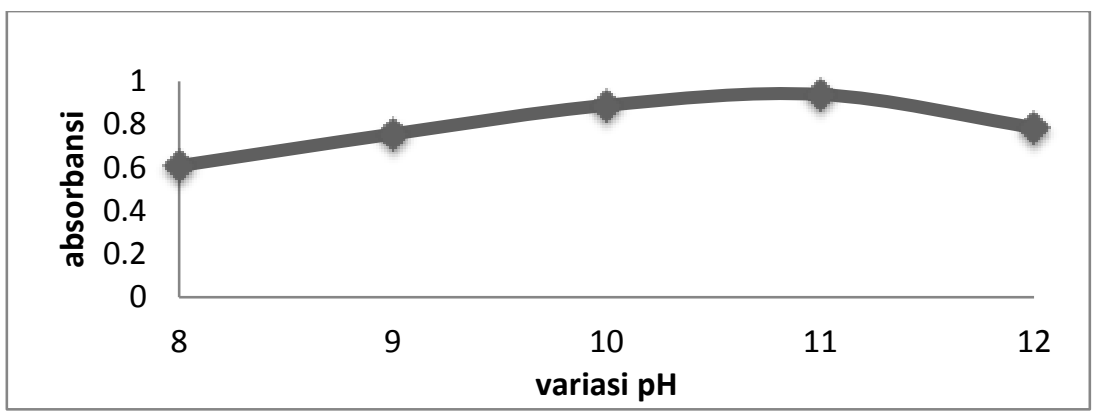

Gambar 4. Kurva variasi pH penentuan panjang gelombang maksimum kompleks

Berdasarkan kurva di atas dapat dilihat bahwa pada $\mathrm{pH} 11$ reaksi antara asam tanat dan ion logam $\mathrm{Cu}$ (II) mencapai kondisi maksimum yaitu pada panjang gelombang 473,5 $\mathrm{nm}$ dengan absorbansi 0,939. Pembentukkan kompleks ion logam $\mathrm{Cu}$ (II) dengan asam tanat terkoordinasi secara optimum pada $\mathrm{pH}$ basa. 


\section{Penentuan Stoikiometri Antara Ion Logam Cu(II) dengan Asam Tanat}

Penentuan Stokiometri Antara Asam Tanat dan Cu(II) dengan Variasi Konsentrasi Asam Tanat : $\mathbf{C u}($ II $)$

Penentuan ini dilakukan dengan cara mengukur kompleks ion logam $\mathrm{Cu}(\mathrm{II})$ dengan asam tanat pada $\mathrm{pH}$ optimum yaitu $\mathrm{pH} 11$ dan panjang gelombang optimum 473,5 nm, nilai serapannya dapat dilihat pada Tabel 7 dan 8 .

Tabel 2. Pengaruh konsentrasi reaksi antara ion logam $\mathrm{Cu}(\mathrm{II})$ dan asam tanat dengan variasi asam tanat

\begin{tabular}{cccc}
\hline Konsentrasi $\mathrm{Cu}-\mathrm{AT}$ & Absorbansi & $\mathrm{pH}$ & Panjang Gelombang \\
\hline $1: 1$ & 0,642 & 11 & 473,5 \\
$1: 2$ & 0,713 & 11 & 473,5 \\
$1: 3$ & 0,788 & 11 & 473,5 \\
$1: 4$ & 0,926 & 11 & 473,5 \\
$1: 5$ & 0,782 & 11 & 473,5 \\
\hline
\end{tabular}

Tabel 3. Pengaruh konsentrasi reaksi antara ion logam $\mathrm{Cu}$ (II) dan asam tanat dengan variasi ion logam $\mathrm{Cu}(\mathrm{II})$

\begin{tabular}{cccc}
\hline Konsentrasi $\mathrm{Cu}-\mathrm{AT}$ & Absorbansi & $\mathrm{pH}$ & Panjang Gelombang \\
\hline $1: 1$ & 0,642 & 11 & 473,5 \\
$2: 1$ & 0,677 & 11 & 473,5 \\
$3: 1$ & 0,701 & 11 & 473,5 \\
$4: 1$ & 0,815 & 11 & 473,5 \\
$5: 1$ & 0,694 & 11 & 473,5 \\
\hline
\end{tabular}

Berdasarkan data yang diperoleh absorbansi optimum ditunjukkan pada perbandingan konsentrasi ion logam $\mathrm{Cu}(\mathrm{II})$ : asam tanat yaitu $1: 4$ dengan absorbansi sebesar 0,926 , sehingga dapat disimpulkan pada konsentrasi asam tanat $4 \mathrm{mM}$ dan ion logam $\mathrm{Cu}$ (II) $1 \mathrm{mM}$ dapat membentuk kondisi optimum kompleks ion logam $\mathrm{Cu}(\mathrm{II})$-Asam Tanat yang dapat ditentukan secara spektrofotometer ultraungu-tampak. Kurva yang terbentuk dari perbandingan konsentrasi ditunjukkan pada Gambar 5. 


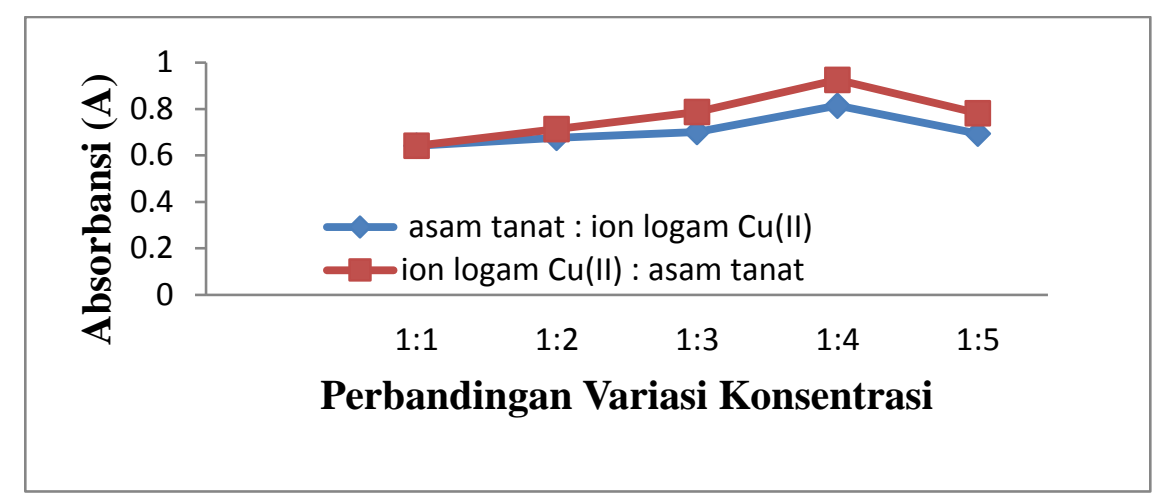

Gambar 5. Kurva Variasi Konsentrasi Asam Tanat : Ion Logam Cu(II)

Berdasarkan kurva variasi konsentrasi dapat dilihat bahwa perbandingan konsentrasi asam tanat : ion logam $\mathrm{Cu}(\mathrm{II})$ adalah 4:1. Konfigurasi elektron dan hibridisasi sebagai berikut :

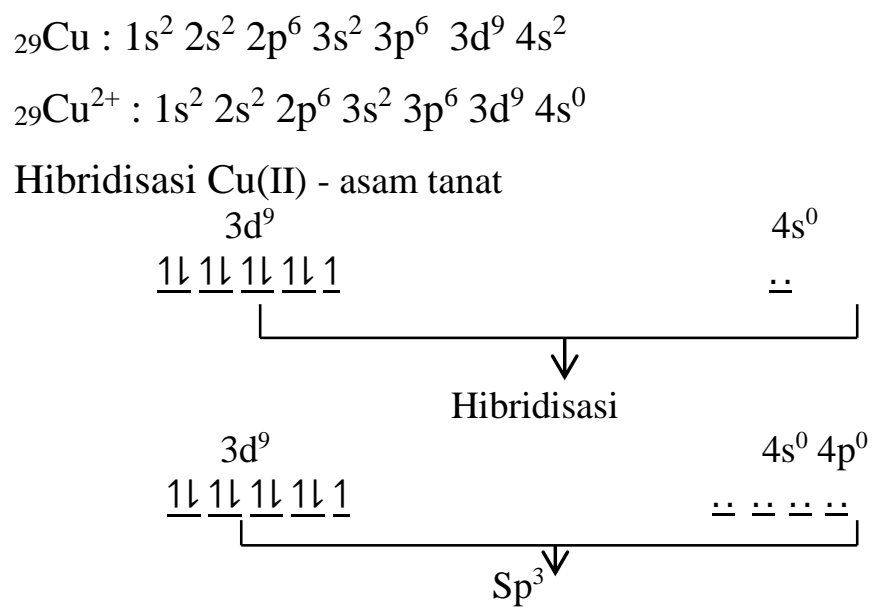

Hasil hibridisasi $\mathrm{sp}^{3}$ pada ion logam $\mathrm{Cu}(\mathrm{II})$ memiliki bentuk geometri tetrahedral yang diperkirakan seperti pada Gambar 6.<smiles>O=C(O)c1cc(O)c2c(c1)OC1(Oc3cc(C(=O)O)cc(O)c3O1)O2</smiles>

Gambar 6. Struktur Tetrahedral Ion Logam Cu(II) Asam Galat (Goh and Huang, 1986; Masoud et al., 2012; Hirotaka et al., 2013; Sanghoon et al., 2015) 


\section{Penentuan Stoikiometri Antara Ion Logam Cu(II) dan Asam Tanat dengan Variasi Volume}

Penentuan ini dilakukan dengan cara mengukur kompleks ion logam $\mathrm{Cu}(\mathrm{II})$ dengan asam tanat pada $\mathrm{pH}$ optimum yaitu $\mathrm{pH} 11$, pada panjang gelombang optimum 473,5 nm, dan pada konsentrasi $1: 4$, nilai serapannya dapat dilihat pada Tabel 9 dan 10 .

Tabel 4. Pengaruh volume reaksi antara ion logam $\mathrm{Cu}(\mathrm{II})$ dan asam tanat dengan variasi asam tanat

\begin{tabular}{ccccc}
\hline Volume $\mathrm{Cu}-\mathrm{AT}$ & Absorbansi & $\mathrm{pH}$ & Konsentrasi & Panjang Gelombang \\
\hline $1: 1$ & 0,994 & 11 & $1: 4$ & 473,5 \\
$1: 2$ & 0,973 & 11 & $1: 4$ & 473,5 \\
$1: 3$ & 0,785 & 11 & $1: 4$ & 473,5 \\
$1: 4$ & 0,675 & 11 & $1: 4$ & 473,5 \\
$1: 5$ & 0,495 & 11 & $1: 4$ & 473,5 \\
\hline
\end{tabular}

Tabel 5. Pengaruh volume reaksi antara ion logam $\mathrm{Cu}(\mathrm{II})$ dan asam tanat dengan variasi ion $\operatorname{logam} \mathrm{Cu}(\mathrm{II})$

\begin{tabular}{ccccc}
\hline Volume $\mathrm{Cu}-\mathrm{AT}$ & Absorbansi & $\mathrm{pH}$ & Konsentrasi & Panjang Gelombang \\
\hline $1: 1$ & 0,994 & 11 & $1: 4$ & 473,5 \\
$2: 1$ & 0,864 & 11 & $1: 4$ & 473,5 \\
$3: 1$ & 0,723 & 11 & $1: 4$ & 473,5 \\
$4: 1$ & 0,562 & 11 & $1: 4$ & 473,5 \\
$5: 1$ & 0,421 & 11 & $1: 4$ & 473,5 \\
\hline
\end{tabular}

Berdasarkan data yang diperoleh absorbansi maksimum yaitu pada perbandingan volume ion logam $\mathrm{Cu}$ (II) dan asam tanat yaitu $1: 1$. Dapat dilihat kurva yang terbentuk pada Gambar 7 .

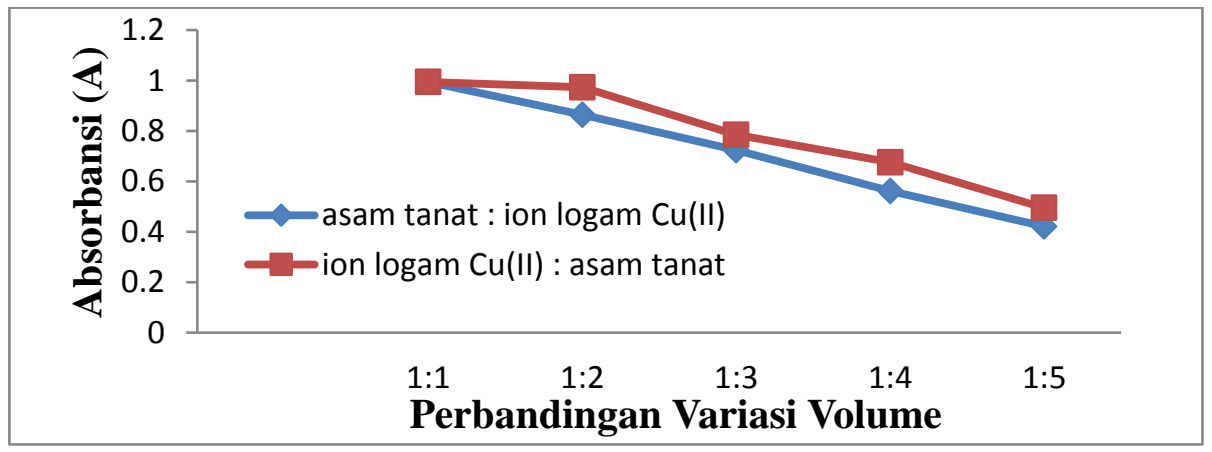

Gambar 6. Kurva Variasi Volume Asam Tanat : Ion Logam Cu(II) 


\section{Penentuan Waktu Kestabilan Kompleks Antara Asam Tanat dengan Cu(II)}

Penentuan waktu kestabilan kompleks dilakukan pada $\mathrm{pH}$ optimum 11, perbandingan variasi konsentrasi terbaik $1: 4$ dan volume terbaik $1: 1$, diukur absorbansinya pada panjang gelombang optimum yaitu 473,5 $\mathrm{nm}$ dari 0 menit sampai 60 menit dengan skala kenaikan 10 menit.

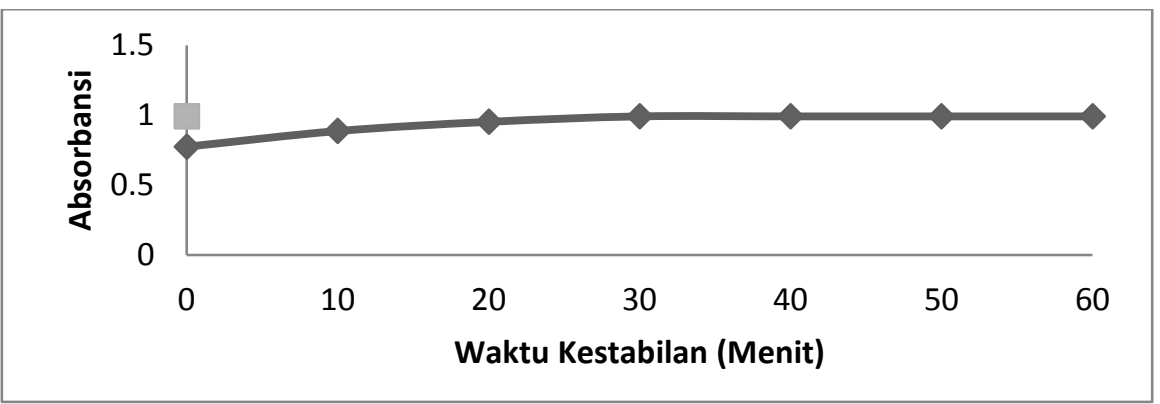

Gambar 7. Waktu Kestabilan Kompleks Asam Tanat dengan Cu(II)

Berdasarkan kurva pada Gambar 7 diperoleh waktu dengan absorbansi optimum yaitu pada menit ke 30 dan dapat dikatakan kompleks asam tanat dengan $\mathrm{Cu}(\mathrm{II})$ cukup stabil.

Validasi Metode: Penentuan Liniearitas Kurva Kalibrasi Larutan Antara Ion Logam $\mathrm{Cu}(\mathrm{II})$

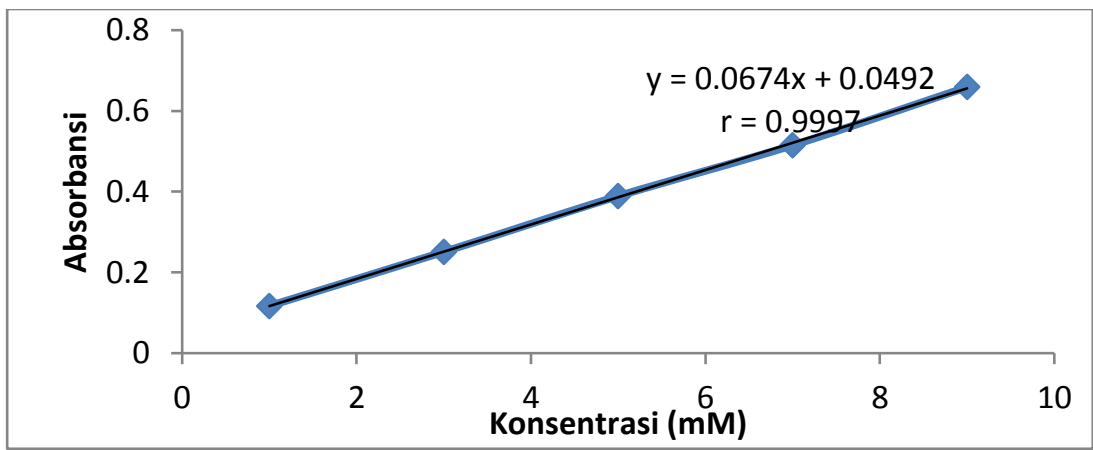

Gambar 8. Kurva liniearitas ion logam $\mathrm{Cu}(\mathrm{II})$

Persamaan garis yang diperoleh dari kurva regresi larutan standar $\mathrm{Cu}(\mathrm{II})$ adalah $\mathrm{y}=$ $0,0674 x+0,0492$ dengan koefisien korelasi sebesar 0,9997. Metode analisis tersebut memenuhi syarat liniearitas yang diterima karena lebih besar dari 0,99 (AOAC, 2002) 


\section{Penentuan Limit Deteksi (LoD) dan Limit Kuantifikasi (LoQ)}

Tabel 6. Nilai LoD dan LoQ ion logam Cu(II)

\begin{tabular}{ccc}
\hline Pengulangan & Absorbansi & konsentrasi terukur \\
\hline 1 & 0,049 & $-0,0029$ \\
2 & 0,048 & $-0,0178$ \\
3 & 0,049 & $-0,0029$ \\
4 & 0,049 & $-0,0029$ \\
5 & 0,049 & $-0,0029$ \\
\hline & Rata-rata & $-0,0059$ \\
& SD & 0,0066 \\
& LoD & 0,2953 \\
& LoQ & 0,9844 \\
\hline
\end{tabular}

Perhitungan dari data yang diperoleh, nilai LoD dan LoQ dapat diterima yaitu 0,2953 dan 0,9844. Berdasarkan baku mutu pencemaran logam $\mathrm{Cu}$ di lingkungan antara 0,2-30 ppm dengan konsentrasi rata-rata 3 ppm (Adriano, 2001).

\section{Presisi}

Tabel 7. Nilai Presisi ion logam $\mathrm{Cu}(\mathrm{II})$

\begin{tabular}{ccc}
\hline Pengulangan & Absorbansi & konsentrasi terukur \\
\hline 1 & 0,107 & 0,8575 \\
2 & 0,108 & 0,8724 \\
3 & 0,109 & 0,8872 \\
4 & 0,107 & 0,8575 \\
5 & 0,108 & 0,8724 \\
\hline & Rata-rata & 0,8694 \\
& SD & 0,0124 \\
& \%RD & 1,4277 \\
\hline
\end{tabular}

Berdasarkan perhitungan dari data yang diperoleh, nilai relatif standar deviasi (RSD) yaitu 1,4277 menunjukkan presisi yang baik karena memenuhi persyaratan nilai relatif standar deviasi (RSD) $\leq 2 \%$ (AOAC, 2002). 


\section{Akurasi}

Nilai \% recovery (perolehan kembali) yang dihasilkan pada analisa ion logam $\mathrm{Cu}(\mathrm{II})$ sebesar $94,54 \%$. Nilai \% recovery yang diperoleh memenuhi persyaratan akurasi yang baik yaitu $92-105 \%$ (AOAC, 2002), sehingga metode ini dapat digunakan untuk menganalisis ion logam $\mathrm{Cu}(\mathrm{II})$.

\section{KESIMPULAN}

Panjang gelombang optimum asam tanat diperoleh sebesar 275,4 nm sedangkan ion logam $\mathrm{Cu}$ (II) sebesar 235,8 $\mathrm{nm}$ reaksi antara asam tanat dan ion logam $\mathrm{Cu}$ (II) diperoleh pH optimum 11 pada panjang gelombang $473,5 \mathrm{~nm}$, perbandingan stoikiometri asam tanat:logam dengan variasi konsentrasi 4:1, variasi volume 1:1 yang diukur pada panjang gelombang 473,8 nm dengan waktu kestabilan 30 menit. Diperoleh hasil r sebesar 0,9997, nilai LoD dan LoQ yang diperoleh sebesar 0,2953 dan 0,9845. nilai SD sebesar 0,0124 dan \%RSD sebesar 1,4277\%. serta nilai \%recovery yang dihasilkan sebesar 94,54\%.

\section{DAFTAR PUSTAKA}

Adriano, D.C. 2001. Trace Elements in Terrestrial Environments. Heidelberg. Berlin.Tampak. Universitas Lampung. Bandar Lampung.

AOAC. 2002. Official Methods of Analysis of AOAC International. AOAC International.

Denny. 2007. Pemanfaatan Tannin Sebagai Perekat. Jurnal Penelitian Fakultas Teknologi Pertanian. Bogor.

Goh, T.B., and P.M. Huang. 1986. Influence of Citric and Tnnic Acids on Hydroxy-Al Interlayering in Montmorillonite. Clays and Clay Minerals. 34(1): 37-44.

Hirotaka, E., J.Joseph., Richardson., K. Liang., J.P. Best., J.P. Best., M.P.V. Koeverden., G.K. Such., J. Cui., F. Caruso. 2013. Science. 341(154): 154-157.

Lee, J. D. 1994. Concise Inorganic Chemistry Fourth Edition. Chapman and Hall. London.

Masoud, M.S., S.S. Hagagg., A.I. Ali., and N.M. Nasr. 2012. Syintesis and Spectroscopic Characteriization of Gallic Acid and Some of its Azo Complexes. Journal of Molekular Structure. 1014: 17-25.

Palar, H. 1994. Pencemaran dan Teknologi Logam Berat. Rineka Cipta. Jakarta. 
Sanghoon, K., S. Philippot., S. Fontanav., R.E. Duval., and Emanuel. 2015. pH And Gluthation Responsive Release of Curcumin from Mesopurous Silica Nanoparticles Coated Using Tannic Acid-Fe(III) Cpmplex. RSC Advance. 5(110): 90550-90558.

Supriyanto, R. 2011. Studi Analisis Spesiasi Ion Logam Cr(III) dan Cr(IV) dengan Asam Tanat dari Ekstrak Gambir Menggunakan Spektrometri UV-Vis. Jurnal Sains MIPA. 17 (1) : $35-42$. 